\title{
The Rise of German Dental Professionalism as a Gendered Project: How Scientific Progress and Health Policy Evoked Change in Gender Relations, c. $1850-1919$
}

\author{
ELLEN KUHLMANN*
}

In Germany, the first efforts to establish dentistry as a medical profession with academic training can be observed around the middle of the nineteenth century. Dentistry was considered at that time to be outside the field of medicine, and thus had no extant scientific tradition. Dental care was largely carried out by laymen with craft-related, technical backgrounds who may or may not have had some knowledge of surgery, but surgeons also occasionally worked in this field. However, it was only when dental problems caused pain or infection that they became a health issue. Most people were dependent on non-professional practitioners, who often offered their services at fairs and markets. The general recognition of teeth as an important health factor came only after experts had acquired the capacity to define health and disease. The lay concept of health did not include dentistry, whereas it had always included medicine independently of and in parallel with the biomedical mainstream.

The rise of the concept of the expert in the nineteenth century, with medical domination and separation of the human body into areas of medical speciality, ${ }^{1}$ promoted the emergence of dentistry as an independent field closely related to scientific medicine. This process of professionalization made quite different impacts on men and women. Despite these gender differences, dentistry has attracted relatively little attention from women's history, whereas medicine has been comprehensively studied. Such studies focus mainly on the exclusion of women

* Ellen Kuhlmann, Dr. soc., MPH, Universität Hamburg, Forschungsgruppe BIOGUM, Falkenried 94, 20251 Hamburg, Germany.

This study was supported by the Graduiertenkolleg Geschlechterverhältnis und sozialer Wandel of the Deutsche Forschungsgemeinschaft. I wish to thank the participants, especially my dissertation supervisors, Prof. Dr. Ursula Müller and Prof. Dr. Mechtild Oechsle for our inspiring discussions. I also wish to thank the anonymous referees and the editors of Medical History for their helpful comments.

\footnotetext{
${ }^{1}$ Sarah Nettleton, Power, pain and dentistry, Buckingham, Open University Press, 1992, describes how in the British dental profession the issue of mouth and teeth came to be separated from the issue of the body and how this process enhanced the power and control of the dental profession.
} 


\section{Ellen Kuhlmann}

from the medical profession or on gendered concepts of illness and healing. ${ }^{2}$ Dentistry, however, raises new and different questions. In this field, professionalization had a contradictory effect on gender relations; because it was orientated on medicine, dentistry became an area of interest for women, thus giving them new prospects. At the same time, new obstacles were created by the medical profession's attempts to exclude women from the universities. In dentistry, women were not completely excluded, but a female tradition of healing and caring was unknown. Early documents on female dentistry show that women carried out a broad variety of tasks ranging from tooth extraction to jaw reconstruction and the preparing of toothpaste. ${ }^{3}$ Professionalization and scientific specialization, however, created a gendered division in dentistry.

The current study looks at the professionalization of dentistry from its beginnings in the middle of the nineteenth century up to its full academic acceptance as an independent profession within the medical field in 1919, when the right to train doctoral students was obtained. This research focuses on the conjunction of the changes in the scientific orientation of dentistry with governmental health policy and gender relations.

German dentistry shows some interesting characteristics: the first efforts in professionalization and women's struggle for admission to the profession occurred simultaneously. Women were excluded from the official profession but as a result of the Kurierfreiheit of $1869^{4}$ the vocational field was still open to them. Even after the end of the Kurierfreiheit, German dental surgeons ${ }^{5}$ did not control

\footnotetext{
${ }^{2}$ Eva Brinkschulte (ed.), Weibliche Ärzte, Berlin, Hentrich, 1993; Katrin Schmersahl, Medizin und Geschlecht, Opladen, Leske und Budrich, 1998; Mary R Walsh, Doctors wanted - no women need apply: sexual barriers in the medical profession, 1835-1975, New Haven, Yale University Press, 1977; Anne Witz, Professions and patriarchy, London and New York, Routledge, 1992; Willem de Blécourt and Cornelie Usborne, 'Women's medicine, women's culture: abortion and fortune-telling in early twentieth-century Germany and the Netherlands', Med. Hist., 1999, 43: 376-92.

${ }^{3}$ Malvin E Ring, Dentistry: an illustrated history, New York, Abrams, 1985; Curt Proskauer, 'Die Zahnärztin in früheren Zeiten', Zahnärztliche Mitteilungen, 1927, 18: 422-3. A recently published study reports archaeological finds dating back to the Roman Empire which may indicate the existence of female dental surgeons even at that early stage, Ernst Künzel, 'Die ersten Chirurginnen der Weltgeschichte', Zahnärztliche Mitteilungen, 1999, 89: 2064-7.

${ }^{4}$ The Kurierfreiheit opened the field of healing to everyone regardless of qualification. Only the titles "doctor" and "dentist" were protected by law; see Hans-Otto Kleinsang, 'Die Einführung der Kurierfreiheit im Jahre 1869 und ihr Einfluß
}

auf die zahnärztliche Approbation', Med. Diss. Berlin, 1931; Kurt Maretzky, 'Die Kurierfreiheit, ihre Auswirkungen auf den zahnärztlichen Stand und ihre Folgen', Zahnärztliche Mitteilungen, 1973, 63: 961-5; Reinhard Spree,

'Kurpfuscherei-Bekämpfung und ihre sozialen Folgen', in Alfons Labisch and Reinhard Spree (eds), Medizinische Deutungsmacht im sozialen Wandel, Bonn, Psychiatrie Verlag, 1989, pp. 103-21.

${ }^{5}$ To avoid confusion, I will use the term "dental surgeon" instead of "dentist" equivalent to the academic trained dentist (Zahnarzt); the term "non-academic dentist" (dentist) describes the heterogenous group of persons offering dental care without academic training; at the very beginning of professionalization this could even mean practising dentistry without any kind of qualification or licence at all. The approbation in dentistry, membership of the profession and its associations, and the dental press were exclusively restricted to dental surgeons. The distinction between academic trained and non-academic dentists is not usually made in England. It is specific to the history of German dentistry, and a consequence of long lasting rivalry and lack of government regulations. 


\section{The Rise of German Dental Professionalism as a Gendered Project}

access to the occupational field for many years. ${ }^{6}$ These specific conditions constructed an asymmetric integration of women into dentistry even while the established professions of the time insisted on a rigid strategy of exclusion. This integration was accomplished by constituting "female" and "male" fields of work.

I will first describe the important steps in the process of professionalization and the main actors within it. ${ }^{7}$ The impact of gender relations is analysed from three different perspectives: the first female dentists and their various approaches to dentistry; the demands and experiences of the women; and the strategy of the dental profession. I will discuss professionalization as a gendered process, although the success of women was not solely related to the "gendering" of speciality areas. Health policy and scientific orientation will also be reviewed, highlighting both the new prospects and the boundaries for women. ${ }^{8}$

\section{Historiography and Sources}

In the history of medicine, there is no substantial body of literature covering the issue of gender and professionalization in dentistry. German female dentists, in particular, have been neglected both by their profession and by their gender. With reference to the professionalization of German dentistry, only very few studies are available and female dentists are not reviewed within feminist research. Women's history has made the women behind the scenes of a profession visible in many areas, but dentistry has not yet been on their agenda.

The work of Dominik Groß analyses the beginnings of German dentistry and offers some helpful information about women in this context, but he does not adopt a gendered approach. ${ }^{9}$ In addition to this, several, mostly unpublished, dissertations are available which bring up various aspects of professionalization, some of which are of a very early date. ${ }^{10}$ Most of these authors do not even

${ }^{6}$ In 1952, the rivalry between dental surgeons and the non-academic dentists came to an end. Since then, dentistry has been restricted by law to dental surgeons only; see, for example, Robert Venter, 'Vom Werden des ZahnheilkundeGesetzes. Ein Rủckblick', Zahnärztliche Mitteilungen, 1973, 63: 966-70.

${ }^{7}$ Ellen Kuhlmann, Profession und Geschlechterdifferenz. Eine Studie über die Zahnmedizin, Opladen, Leske und Budrich, 1999.

${ }^{8}$ This paradox is analysed in contemporary organizational studies, e.g. Susan Halford, Mike Savage and Anne Witz, Gender, careers and organisations, Basingstoke, Macmillan, 1997; Jeff Hearn, 'On ambiguity, contradiction and paradox in gendered organizations', Gender, Work and Organization, 1998, 5: 1-2. It could be an interesting approach to historical studies, too.

${ }^{9}$ Dominik Groß, Die schwierige Professionalisierung der Deutschen Zahnärzteschaft (1867-1919), Frankfurt am Main, Peter Lang, 1994.

${ }^{10}$ Ulrich Axmann, 'Die Entwicklung des Kassenzahnarztwesens der Stadt Hamburg', Med.
Diss., University of Hamburg, 1984; Erwin

Beutel, 'Die Entstehung des Zahnärztestandes in Deutschland', Med. Diss., University of Mainz, 1982; Paul Fischer, 'Die Geschichte der

Krankenkassen unter besonderer Berücksichtigung des zahnärztlichen Krankenkassenwesens', Med. Diss., University of Greifswald, 1921; Johan Jost, 'Entwicklung des zahnärztlichen Berufsstandes im 19. Jahrhundert', Med. Diss., University of Zürich, 1960;

Kleinsang, op. cit., note 4 above; Hans Vogel, 'Die Entwicklung der kassenzahnärztlichen Versorgung', Med. Diss., University of Hamburg, 1951; Rudolph Weiße, 'Geschichte und Methodik der Jugendzahnpflege in Deutschland und einigen Nachbarstaaten', Med. Diss., University of Bonn, 1977; Karl Ziegeler, 'Der aus der Reichsversicherungsordnung entstandene Streit zwischen Zahnärzten, Ortskrankenkassen und Zahntechnikern', Med. Diss., University of Heidelberg, 1922; Bruno Zimmermann, 'Der amerikanische Einfluß auf die deutsche Zahnheilkunde im ausgehenden 19. Jahrhundert', Med. Diss., University of Bonn, 1969. 


\section{Ellen Kuhlmann}

mention that there were two sexes in the profession and that the sphere of influence was unequally distributed between men and women. However, several women have focused on the history of early female dental surgeons in their doctoral theses, thereby providing valuable information about the situation of women. ${ }^{11}$ We also find information about women in the American literature ${ }^{12}$ and in some articles of the German dental press. At the turn of the nineteenth century, the emergence of professional training for women was closely observed by the women's movement. Some mention of female dental surgeons can be found here, too. ${ }^{13}$

The question of how dentistry came to be gendered and the paradox of the oppressive and enhancing impact of professionalism on women's access to the dental profession have not yet been analysed. ${ }^{14}$ The source material is extremely difficult to trace, especially at the personal level. Very few of the early women in dentistry have left any written material. There is also very little reference in the dental press to the situation of women. Even statistics are few and those available are often contradictory.

\section{First Efforts in Professionalization: A Men's Project}

Among the health professions in Germany, dentistry was the last to receive government recognition. The Prussian Medizinalordnung of 1825 was the first official document to mention dental care in connection with the medical profession and it also outlined some formalized regulations. Dental surgeons were usually

\footnotetext{
${ }^{11}$ Eva Balschbach, 'Frauen in der Zahnheilkunde Deutschlands', Med. Diss., University of Berlin, 1990, is the most interesting of these studies; further information can be found in: Jutta Christoph, 'Die Stellung und Bedeutung der Frau in der Zahnheilkunde Hamburgs', Med. Diss., University of Hamburg, 1953; Ilse Gabrys, 'Die Frau in der Medizin und Zahnmedizin', Med. Diss., University of Aachen, 1987; Erika MonseSchneider, 'Frauen im zahnmedizinischen Studium und Beruf', Med. Diss., University of Münster, 1991. A recently published study, Cecile Mack, Henriette Hirschfeld-Tiburtius (1834-1911), Frankfurt, Peter Lang, 1999, provides comprehensive information of the first German female dental surgeon.

${ }^{12}$ Committee on Historical Research on the Federation of American Women Dentists, 'Women in dentistry 1855-1889', J. Am. Dent. Assoc., 1928, 15: 1735-56; James Truman, Henriette Hirschfeld, 'D.D.S. and the Women Dentists of 1866-73', Dental Cosmos, 1911, 53: 1380-6.
}

\author{
${ }^{13}$ Die Frau, 1893, 1, to 1920, 28. \\ ${ }^{14}$ The gender studies of professionalization \\ were influential for the development of a \\ theoretical framework, see Ilse Costas, 'Das \\ Verhältnis von Profession, Professionalisierung \\ und Geschlecht in historisch vergleichender \\ Perspektive', in Angelika Wetterer (ed.), \\ Profession und Geschlecht, Frankfurt, Campus, \\ 1992, pp. 115-44; Angelika Wetterer (ed.), Die \\ soziale Konstruktion von Geschlecht in \\ Professionalisierungsprozessen, Frankfurt, \\ Campus, 1995; Witz, op. cit., note 2 above. Also \\ important were the theories of \\ professionalization, see Andrew Abbott, The \\ system of professions, Chicago University Press, \\ 1988; Terence Johnson, Professions and power, \\ London, Macmillan, 1972; Magali S Larson, The \\ rise of professionalism, Berkeley, University of \\ California Press, 1977; Noel Parry and Jose \\ Parry, The rise of the medical profession, London, \\ Croom Helm, 1976.
}




\section{The Rise of German Dental Professionalism as a Gendered Project}

assigned to the lowest class in medicine, the so-called second class Wundärzte (low prestige surgeons). Almost any barber, lay health worker, goldsmith or travelling businessman who had the basic technical tools for dentistry and who advertised his business accordingly, could work as a dentist. ${ }^{15}$

It was not the lack of qualifications which led to the de facto exclusion of women in the early days of professionalization but rather the male-centred tradition in the professional fields from which dentistry evolved. Only men could become surgeons, barbers and goldsmiths. Indeed, travelling trades were not possible for women since they were inevitably associated with prostitution. Professional access through the medical schools was denied women anyway. They could not even train to be low prestige Wundarzt because this was traditionally a military occupation and women were excluded from the German military forces. Hence there was not even a need for the explicit exclusion of women because cultural traditions in the professions and the circumstances of professional practice served as very effective barriers.

The efforts to professionalize dentistry were begun by men who were obviously intent on establishing class boundaries. In 1850, Prussia had a mere 103 dental surgeons, and in the German Reich there were only 250; before 1884, the number of dental surgeons with a German approbation grew to a mere 451, said to be scattered across 154 cities. $^{16}$ This small group could not guarantee to serve the whole population, yet it claimed exclusive rights to the vocational field and set up rigid boundaries against other professions. In so doing, dental surgeons showed a much stronger cohesion and a higher self-esteem than men in other rising professions. The strategy was aimed in two directions: against the medical profession, who did not accept dental surgeons as equal colleagues, and against all unqualified, non-academic dentists who belonged to lower social classes. Prussian health care legislation had tried to achieve unity within the medical field by integrating the lower classes of surgeons (first and second class Wundärzte), but dentists strongly rejected this integration and steadfastly demanded their independence. ${ }^{17}$ Around the middle of the nineteenth century, we find clear tendencies towards professionalism: in 1846 the first dental journal was founded in Berlin. The founding of associations on a community basis followed and the national union of dental surgeons, the Centralverein, was founded in 1859, with the principal aims of defending professional interests against government regulation and improving scientific knowledge. ${ }^{18}$ In 1889 , regulations for examination required both higher education and three years of specialized study. ${ }^{19}$

\footnotetext{
${ }^{15}$ See Georg Pierce Geist-Jacobi, Geschichte der Zahnheilkunde, Tübingen, Pietzcker,1896, pp. 239-49; Walter Weddigen (ed.), Entwicklung, Struktur und Situation des zahnärztlichen Heilberufs, Munich, Kartei Verlags-Dienst, 1958.

${ }^{16}$ Anonymous, 'Statistiken', Der Zahnarzt, 1850, 6: 376; Adolf Petermann, 'Des Deutschen Reiches Zahnärzte', Deutsche Monatsschrift für Zahnheilkunde, 1884, 2: 78-80.
}

\footnotetext{
${ }^{17}$ See Joachim v. Reckow, Grundlagen zur Geschichte der deutschen zahnärztlichen Approbation, Greifswald, Verlag Bamberg, 1927.

${ }^{18}$ See Adolf Petermann, 'Des Deutschen

Reiches zahnärztlichen Vereine', Deutsche Monatsschrift für Zahnheilkunde, 1884, 2: 207-8, Jost, op. cit., note 10 above, p. 44.

${ }^{19}$ In the 1880 s education was a major topic in the dental press. Special issues of the
} 


\section{Ellen Kuhlmann}

The main objectives of dentistry were orientated towards surgery and medicaltechnical progress. Due to the academic acknowledgement of surgery, ${ }^{20}$ dental surgeons had to struggle for participation in this upgraded field. They saw themselves as part of the medical profession but did not want to be subjected to the physicians' rule. The orientation towards medicine and away from (travelling) trade was important because it created conditions that made the dental profession attractive to women, too. But it also created new obstacles in that the German medical profession fought bitterly against the admission of women to the universities. ${ }^{21}$

The history of women's involvement in dentistry in Germany can be traced as far back as the twelfth century, in the work of Hildegard von Bingen. ${ }^{22}$ Women were often introduced to dentistry by their husbands or male relatives ${ }^{23}$ and so entered sideways into that occupation. In 1884, for example, Anna Seethaler can be found on the register of dental surgeons with a German approbation. But there is no further information about her. ${ }^{24}$ At the beginning of the professionalization process, therefore, women were not completely excluded from dentistry, but were represented on a very small scale only. Male dominance in dentistry in Germany is even more obvious when compared with developments in the United States and in Great Britain. There are reports of female dentists in Britain dating back to the eighteenth century, and to the nineteenth century in the United States. ${ }^{25}$ As in Germany, however, these cases seem to have been exceptional. Despite significant differences in professionalization in all three countries, a common factor is the extremely low participation of women from the very beginning. There can be no doubt that dentistry in both Britain and America evolved in its own unique way within the medical field, just as it did

Deutsche Monatsschrift für Zahnheilkunde give an idea of the discussion within the profession, see, for example, Julius Parreidt, 'Verlängerung des zahnärztlichen Studiums', Beiblatt zur Deutschen Monatsschrift für Zahnheilkunde, 1888, 6: 53-64; Otto Walkhoff, 'Zur Verlängerung des zahnärztlichen Studiums', Beiblatt zur Deutschen Monatsschrift für Zahnheilkunde, 1888, 6: 73-80.

${ }^{20}$ Vincent Czerny, Über die Entwicklung der Chirurgie während des 19. Jahrhunderts und ihre Beziehung zum Unterricht, Heidelberg, Universitäts-Buchdruckerei, 1903; for a summary, see Sabine Sander, Handwerkschirurgen,

Göttingen, Vandenhoeck \& Ruprecht, 1989.

${ }^{21}$ See, for example, Theodor L W Bischoff, Das Studium und die Ausübung der Medicin durch Frauen, Munich, Literarisch-Artistische Anstalt, 1872; Arthur Kirchhoff (ed.), Die akademische Frau, Berlin, Steinitz, 1897.

\footnotetext{
${ }^{22}$ Ingeborg Hertelendy-Michel, 'Die Frau im zahnärztlichen Beruf', Zahnärztliche Mitteilungen, 1965, 55: 409-12, 507-11, 616-20; Peter Riethe, 'Zahnärztliches aus den Werken St. Hildegards von Bingen', Zahnärztliche Mitteilungen, 1954, 42 : 779-82.

${ }^{23}$ Groß, op. cit., note 9 above; Proskauer, op. cit., note 3 above.

${ }^{24}$ Petermann, op. cit., note 18 above, p. 207.

${ }^{25}$ For the UK, see J Menzies Campbell, 'Early women dentists', Br. Dent. J., 1947, 82: 123-4; Edwina Kidd, 'Dental suffragettes-women in dentistry', Dental Update, 1974, Jan./Feb., 249-52; Edith J Morley, Women workers in seven professions: a survey, London, Routledge, 1914, pp. 167-70; for the US, see Hannelore T Loevy and Aletha A Kowitz, 'Founders of the American Association of Women Dentists: their legacy lingers on', Int. Dent. J., 1991, 41: 240-7; Ring, op. cit., note 3 above.
} 


\section{The Rise of German Dental Professionalism as a Gendered Project}

in Germany, but professionalization there started earlier ${ }^{26}$ and women were also admitted to dental schools earlier. It was by no means specific to conditions in Germany that dentistry was a project of male actors. It was typical for the profession in western industrialized countries.

\section{The Struggle for Academic Acknowledgement: Beginning of an Asymmetric Integration of Women}

From 1896 to 1919, important steps towards professionalism were taken in Germany. An inner and outer solidarity of the profession had been secured and governmental acknowledgement and admission to the academic field had been achieved. In 1869, two important events took place in the Norddeutscher Bund: the Kurierfreiheit ${ }^{27}$ in the medical field, and the new regulation of examinations. Both were extended to the German Reich in 1871. The improvement of academic training (and the rise in social status that followed) can be judged as an enhancing factor in professionalization, but its effects were questionable because it opened up the whole of medicine to unqualified persons. Dental surgeons viewed the Kurierfreiheit only as an obstacle to professionalization and to gaining social status. ${ }^{28}$ From a female point of view, however, the Kurierfreiheit offered women the possibility, for the first time, to circumvent their exclusion from universities and to make use of that chance to work in dentistry. ${ }^{29}$ At the same time, dentistry's links with the medical profession became closer. The 1909 regulations for examination enrolment shifted dentistry from the philosophy department to the medical department. The programme was extended to seven terms and medical schools served as a model for the curriculum. ${ }^{30}$ As a result, maturity became a prerequisite for studying dentistry, bringing an adjustment and a rise in the dental surgeons' social status. In 1919, for the first time, a dissertation in dentistry was possible. Through their integration into the medical profession, dental surgeons acquired strategies of closure and exclusion through qualification, but they could not make use of them since women had already crossed that boundary. ${ }^{31}$

Dental surgeons' lack of the control of admission to the vocational field and their rivalry with other groups are important factors in the development of a

\footnotetext{
${ }^{26}$ For the USA, see Ring, op. cit., note 3 above; for the UK, see Eric G Forbes, 'The professionalization of dentistry in the United Kingdom', Med. Hist., 1985, 29: 169-81; N David Richards, 'Dentistry in England in the 1840s: the first indications of a movement towards professionalization', Med. Hist., 1968, 12: $137-52$.

${ }^{27}$ See note 4 above.

${ }^{28}$ See, for example, Jost, op. cit., note 10 above, p. 48; Kleinsang, op. cit., note 4 above; Maretzky, op. cit., note 4 above.
} 


\section{Ellen Kuhlmann}

specific form of integration of women into the profession. Because of the Kurierfreiheit, competition was strong from the beginning and continued to be so for a long period. The struggle against Pfuschertum, as dental surgeons called dental care by non-academic dentists, dominated the debates within the profession. ${ }^{32}$ It was not until 1952 that the German government gave support to the dental surgeons and introduced clear regulations restricting the vocational field exclusively to academically trained members. ${ }^{33}$ One reason for the government's reluctance to intervene was the very low number of dental surgeons even in the twentieth century. The situation for people living in country areas was particularly bad because they had very little access to services. Dental surgeons worked primarily in the cities: in the German Reich there were only 59 dental surgeons in communities of less than 5,000 people, although half the population lived in such communities. It is significant that there was a ratio of 10 dental surgeons to 295 non-academic dentists. ${ }^{34}$

With the introduction of the German health insurance (Gesetzliche Krankenversicherung) in 1884, which secured general health care for the population, economic factors were also reviewed because non-academic dentists worked for much lower rates than their academic colleagues. ${ }^{35}$ The introduction of the health insurance system led to an enormous expansion of dental care services. But because Prussian law did not make clear definitions and regulations of professional competence, ${ }^{36}$ dental surgeons could not control this market. The 1883 health insurance legislation did not grant a right to dental care. ${ }^{37}$ Only the extraction of painful teeth was accepted as essential treatment. The costs of other types of dental services were not provided for, and the handling of this varied from region to region. Until the end of the nineteenth century, health insurance agencies often refused to pay for restorative dentistry, ${ }^{38}$ and physicians were frequently consulted for treatment. Finally, the 1917 decree of the health care administration forced the health insurance agencies to pay for restorative therapy. ${ }^{39}$ Dental surgeons had to fight both for their right to control this field and for the acceptance of dental care as a public health issue. By this time, dental surgeons needed to secure recognition of their interests not only by the government but increasingly by the health insurance administration.

This was not only a period of rivalry but also of great scientific progress in dentistry. Notwithstanding its traditional roots in surgery, the focus of dentistry

\footnotetext{
${ }^{32}$ See Ferdinand Baden, Rechtsstaat und Kurpfuschertum, Berlin, Schmidt und Buhofer, 1914; Spree, op. cit., note 4 above.

${ }^{33}$ See note 6 above.

${ }^{34}$ Alfred Kantorowicz, Die Zukunft der Zahnheilkunde und die zahnärztliche Sanierung des deutschen Volkes, Berlin, Verlag Hermann Meusser, 1919; see also Alfred Cohn, Leitfaden zum Studium der sozialen Zahnheilkunde, Berlin, Hermann Meusser, 1922, pp. 27-30.
} 


\section{The Rise of German Dental Professionalism as a Gendered Project}

became broader and close links were established with other medical fields. Intraprofessional specialization made most progress and in 1908, the Deutsche Gesellschaft für Orthodontie (German Association of Orthodontics) was founded. ${ }^{40}$ Public health initiatives had preceded this scientific development. In 1879, the first group examination of children took place and demand for institutionalized dental care in schools grew in the following years. By 1909, 23 school based dental clinics were in existence. Alfred Kantorowicz, a pioneer in the public health sector, introduced the "Bonner System" in 1912, which offered collective free dental health care for children of every social class. ${ }^{41}$ During the First World War, school dentistry declined as a result of financial and staff shortages, and women quite often replaced school dental surgeons who had been drafted into military service. ${ }^{42}$ Even before this, however, school dentistry gave women a chance to set up their own vocational field. ${ }^{43}$ Within the profession itself, this area had been debated as a possible area of work for women. Within the overall movement towards professional expansion, different processes took place simultaneously: attempts were made to establish a new field parallel to the mainstream of scientific-technical dentistry and to sex-type it because of women's alleged natural ability to treat children.

\section{Access of Women to Dentistry}

Compared with other countries, Germany was rather late in starting the professionalization process in dentistry and it was also late in opening universities for women. Yet Kurierfreiheit offered women various alternative chances to achieve the necessary skills and rights to enable them to work in dentistry. As long as women did not try to get official recognition as dental surgeons, their work was not under the control of the profession.

Contemporary evidence suggests that opportunities in dentistry for women even without academic training were quite favourable because patients could rarely distinguish dental surgeons from non-academic dentists. ${ }^{44}$ Many women used these opportunities. The ratio of women among non-academic dentists in the German Reich in 1898 was 4.2 per cent rising to 9.4 per cent in $1909 . .^{45}$ The numbers of women dentists without approbation remained for a long time significantly higher than those with academic training. In Hamburg, for example, where the situation

\footnotetext{
${ }^{40}$ Karl Bernklau and Kurt Bertzbach, Geschichte der Deutschen Gesellschaft für Kieferorthopädie (1907-1978), Munich, Urban und Schwarzenberg, 1981, p. 11.

${ }^{41}$ GroB, op. cit., note 9 above; Norbert Guggenbichler, Zahnmedizin unter dem Hakenkreuz, Frankfurt, Mabuse, 1988; Weiße, op. cit., note 10 above; Vogel, op. cit., note 10 above.

${ }^{42}$ GroB, op. cit., note 9 above.

${ }^{43}$ Ida Freudenheim, Die Zahnärztin. Aussichten, Leistungen und Forderungen in diesem
}

Beruf, Leipzig, Bange's Verlag, 1904; Elisabeth Schenk, 'Die Bedeutung der Schulzahnklinik für die Schulzahnpflege', Soziale Medizin, 1928, 1: 249-54.

${ }^{44}$ Anon., 'Zur Frauenfrage', Zahnärztliches Wochenblatt, 1892/93, 6: 73-4.

${ }^{45}$ Own calculations based on data given by Gabrys, op. cit., note 11 above, p. 99. 


\section{Ellen Kuhlmann}

is relatively well documented, 23 non-academic female dentists registered in 1904. In 1925, there were only 21 female dental surgeons but 101 female non-academic dentists. ${ }^{46}$

From the start, women's entry into dentistry was never a struggle for the vocational field because this had already been occupied successfully with little effort and resistance by female non-academic dentists. The female dental surgeons' professional strategy must be seen as embedded in women's wider struggle for education and access to male dominated and privileged professions at that time. ${ }^{47}$ The very different reactions of the dental profession and of non-academic dentists towards the participation of women ${ }^{48}$ proves again that the real point at issue was not women's ability to work in dentistry, but rather the privileges and power of the male players. Whereas in the past, women had gained access mostly through their husbands or male relatives, they now began to make demands for an academic curriculum. Until the end of the nineteenth century, the only possibility for women to attain an academic education in dentistry was to join a programme in the USA. Henriette Hirschfeld was a pioneer here. In 1869, she became the second woman in the United States to receive a Doctorate in Dental Surgery (DDS) at the Pennsylvania College of Dental Surgery. ${ }^{49}$ After this successful beginning, the number of female dental surgeons in the USA rose continuously. ${ }^{50}$ Henriette Hirschfeld preceded both American and German women: Marie Grubert, Emilie Wiede-Foeking, Valeska Wilcke and Louise Jacoby graduated soon after her. ${ }^{51}$ By 1894 , there were 30 US trained women practising dentistry in Germany while women were still struggling for academic acknowledgement. Between 1869 and 1909, 45 women graduated with a DDS. ${ }^{52}$ Early professionalization in dentistry and the early admission of women to higher education in the United States also promoted the academic effort of German women. ${ }^{53}$ Despite their success in the USA, Henriette Hirschfeld and Marie Grubert returned to Germany. Hirschfeld opened a surgery in 1869 as a "woman's and child dentist" and by 1874 she was so successful that she took the Baltimore

\footnotetext{
${ }^{46}$ Ibid., pp. 42-30.

${ }^{47}$ See, for example, Elisabeth Gnauck-Kühne, Das Universitätsstudium der Frauen. Ein Beitrag zur Frauenfrage, Oldenburg and Leipzig, Schulzesche Hof-Buchdruckerei, 1891; Helene Lange, 'Der vierte Weg zur Universität', Die Frau, 1909, 17: 141-6.

${ }^{48}$ There is no indication that the nonacademic dentists restricted the access of women; see Gabrys, op. cit., note 11, pp. 47-8; Barbara Mair, 'Die Entwicklung des Standes der Dentisten', Med. Diss., University of Munich, 1986.

${ }^{49}$ Committee on Historical Research, op. cit., note 12 above; see Mack, op. cit., note 11 above.

${ }^{50} \mathrm{M} \mathrm{D} \mathrm{K}$ Bremner, The story of dentistry: from the dawn of civilization to the present,
}

Brooklyn NY, Dental Items of Interest Pub. Co., 1946, pp. 297-302; Loevy and Kowitz, op. cit., note 25 above; Mack, op. cit., note 11, pp. 92-6.

${ }^{51}$ Committee on Historical Research, op. cit., note 12 above, pp. 1755-6.

${ }^{52}$ Gertraud Bäumer, 'Zur Soziologie des Frauenstudiums', Die Frau, 1912, 19: 455-64, $555-65$, p. 562 .

${ }^{53}$ The DDS was not of advantage to women only, German men also made use of this qualification to improve their training and to achieve a higher status within the profession. All the same, the impact was quite different: men had the option to choose a German or an American programme, women did not; joining a programme in the USA was the only chance for women to surmount the obstacles in Germany. 


\section{The Rise of German Dental Professionalism as a Gendered Project}

College graduate Louise Jacoby into partnership. ${ }^{54}$ Although they were very highly qualified, these women were still exposed to the hostility of their male colleagues. Until the beginning of the twentieth century, German women had to travel as far as the USA to receive professional training in dentistry but in Great Britain there was no similar impulse. Dentistry there was quite advanced, but women's chances were much lower than in the United States: Lilian Murray, known later as Lindsay, was the first woman to graduate in British dentistry as late as 1895 from Edinburgh. ${ }^{55}$ It was not until seventeen years later, that the next woman took her exams in London. ${ }^{56}$ Women with a certificate from abroad or without a licence had practised dentistry before that in Great Britain. The 1871 British Census, which classified gender for the first time, registered 116 female dental surgeons. ${ }^{57}$ The late entrance of British women into academic dentistry is even more striking when compared with their vigorous efforts to enter medicine, and their success in that endeavour after circa $1880 .{ }^{58}$ The difference in access of women to both dentistry and medicine shows not only that national conditions but also that conditions specific to given professional groups deserve consideration.

The first woman in Germany to take exams in dentistry was Ida Freudenheim in Breslau in 1901; and the first two female students were admitted to the wellknown Institute for Dentistry in Berlin in 1902. Three years later two other women graduated in dentistry in Germany, one each from Leipzig and Rostock. ${ }^{59}$ In 1909, 36 women studied dentistry in the German Reich and 38 female students were enrolled in each of the summer terms of 1910 and $1911 .{ }^{60}$ Up to 1912 , a total of 60 female graduates were registered in dentistry ${ }^{61}$ and in 1917 this number had reached $100 .{ }^{62}$ In 1919 , there were an estimated 150 female dental surgeons in Germany, 3.3 per cent of the total profession at the time. ${ }^{63}$ The number of women enrolling during the first years after the universities opened to them was not very high. Getting professional training was the main difficulty for women at the time. Access to the vocational field, on the other hand, was not under the profession's control and, since patients were already used to women working in the field because female non-academic dentists were fairly common, they were accepted quite readily.

${ }^{54}$ Adelheid Jacobi, 'Frau Dr. Henriette Tiburtius', Archiv der Zahnheilkunde, 1911, 12: 11-12; see Mack, op. cit., note 11 above, pp. 117-18.

${ }^{55} \mathrm{E} M$ Cohen and $\mathrm{R}$ A Cohen, 'The autobiography of Dr. Lilian Lindsay', Br. Dent. J., 1991, 171: 325-8; Forbes, op. cit., note 26 above, p. 170.

${ }^{56}$ Robert Bradlaw, 'Milestones', Br. Dent. J., 1967, 123: 340-5.

${ }^{57}$ Committee on Historical Research, op. cit., note 12 above, p. 1735.

\footnotetext{
${ }^{58}$ See Edythe Lutzker, 'The London School of Medicine for Women', Proceedings of the XXIII Congress of the History of Medicine, 1974, 357-66.

${ }^{59}$ See Freudenheim, op. cit, note 43 above.

${ }^{60}$ Anon., 'Meldungen zum Frauenstudium', Die Frau, 1909, 16: 306; 1910, 17: 688; 1911, 18: 691.

${ }^{61}$ Bäumer, op. cit., note 52 above, p. 562.

${ }^{62}$ Max Hirsch, Über das Frauenstudium, Leipzig, Verlag von Curt Kabitsch, 1920, p. 46.

${ }^{63}$ See Groß, op. cit., note 9 above, p. 345.
} 


\section{Ellen Kuhlmann}

Like Henriette Hirschfeld, the first six female dental surgeons to be trained in German universities went on to run their own practices. ${ }^{64}$ Jutta Christoph has discovered that the majority of female dental surgeons registered in the city of Hamburg from 1880 to 1920 had their own surgery. ${ }^{65}$ Self-employment was obviously highly valued by women. Apart from this, the new field of school dentistry offered further occupational possibilities for women. There are no statistical data available, but contemporary writings, mostly by female dental surgeons, bear witness to their work in school dentistry. ${ }^{66}$ Most of these women remained nameless and unnoticed by the wider profession. Elisabeth Schenk was the first woman in school dentistry mentioned by name in the dental press. She described her strong motivation for this area of work; and we learn from her experience that it was easy to find employment. In 1902, she got a well-paid job at a school dental clinic in the middle of Germany. She did not report any problems or negative attitudes against women. ${ }^{67}$

Things were less favourable for women when it came to their admission to the professional associations. Even in 1899, the simple wish of a female dental surgeon to participate in a conference was not approved. ${ }^{68}$ In 1904 , the first woman applied for membership of the Centralverein Deutscher Zahnärzte, the German Dental Association. ${ }^{69}$ Women were admitted to students' organizations in $1907 . .^{70}$ Long before this, German female dental surgeons had joined dental associations in the US. Marie Grubert was the first woman to take on a leading position when in 1872 she was elected vice president of the Mississippi Valley Association of Dental Surgeons. ${ }^{71}$ Henriette Hirschfeld was a member of the Women's Advisory Council at the World Congress of Dentists in $1893 .^{72}$ If women in the nineteenth century were still formally and later de facto excluded from associations, it was not solely because of the attitudes of their male colleagues but also because of their own failure to found women's associations such as were established in the USA at an early stage in professionalization. ${ }^{73}$

\footnotetext{
${ }^{64}$ Die Frau, 1906, 13: 243.

${ }^{65}$ Christoph, op. cit., note 11 above, p. 33

${ }^{66}$ See note 43 above; Anon., Deutsche Monatsschrift für Zahnheilkunde, 1908, 26: 941; Groß, op. cit., note 29 above, p. 11. The few essays of that time written by women pointed out the occupational chances of women in school dentistry; still there was not any kind of reference to women in the work of male actors engaged in this field, for example, Kantorowicz, op. cit., note 34 above; Cohn, op. cit., note 34, above; Alfred Cohn, Die Verstaatlichung der Zahnheilkunde, Berlin, Hermann Meusser, 1921; Konrad Cohn, op. cit., note 38 above.

${ }^{67}$ Schenk, op. cit., note 43 above, p. 250.

Elisabeth Schenk later worked with Alfred

Kantorowicz.
} 


\section{The Rise of German Dental Professionalism as a Gendered Project \\ How Women Staked out the Vocational Field and Offered Gendered Interpretations}

We know that Henriette Hirschfeld could look back on a fulfilled working life with a successful practice among women and children, who quite often came from a well-to-do social background. Exceptionally, she also treated men. ${ }^{74}$ Hirschfeld herself wrote about her motives and her experiences in a letter which is quoted here:

After being left a widow and thrown upon my own resources, I looked to see how women supported themselves. I saw how they were shut out from many occupations suited to their sex and abilities, and how they had to work for a trifle, or how ill they were treated because the few places open to them were overfilled. Fully convinced that this state of affairs had to be changed in many respects, I concluded to do my part in taking up and carrying out my old favorite idea; so I came to Philadelphia with full confidence in the liberal minded Americans.... I have not been mistaken in my people, or in the wants of my time. It is now nine months since I opened my office, and my success has far exceeded my expectations. Nearly half of my patients belong to our aristocracy, and two of the royal princesses are among them.... The journals have spread my history over the continent, and from all parts of the country I receive letters of thanks and encouragement. Mothers are delighted that I take especial care of children, and they place their little ones with confidence under my charge. ${ }^{75}$

Hirschfeld saw her own work as part of the women's liberation movement's struggle for education and qualified jobs: "And I am working for our case daily", ${ }^{76}$ she wrote in the letter quoted above. Neither marriage nor maternity limited Hirschfeld's involvement and after giving birth to her two sons, she intermitted her work for just a few weeks. ${ }^{77}$ As far as the available information shows, Hirschfeld did not talk much about her own situation as a working woman in Germany, but discussed her activities in terms of improving the lot of socially disadvantaged women. She demonstrated her professional interests by publishing articles and lecturing at conferences in the USA, but apparently rarely in Germany. ${ }^{78}$

In 1896, for the first time, a female dental surgeon joined the debate in the dental press about professional women. $\mathrm{R}$ Kowarski-Blanc, about whose education

\footnotetext{
${ }^{74}$ Hertelendy-Michel, op. cit., note 22 above, pp. 507-8; Jacobi, op. cit., note 54 above; Mack, op. cit., note 11 above, p. 105.

${ }^{75}$ Quoted from Committee on Historical Research, op. cit., note 12 above, pp. 1741-2.

${ }^{76}$ See ibid.

${ }^{77}$ Mary Murchall, 'Dr. Henriette Tiburtius', Die Frau, 1894, 2: 82-5.

${ }^{78}$ Mack, op. cit., note 11 above, pp. 112-116, quotes an essay that bears witness to Hirschfeld's
}

\author{
high professional competence, especially her \\ interest in dental prevention: Henriette \\ Hirschfeld, 'Die Pflege der Zähne und des \\ Mundes', Der Frauen-Anwalt, 1881/82, 2: 419-22; \\ Hirschfeld concentrated her strategy on \\ individual prevention, whilst other women \\ advocated group prevention; see Schenk, op. cit., \\ note 43 above; Freudenheim, op. cit., note 43 \\ above, p. 24.
}




\section{Ellen Kuhlmann}

nothing is known, wrote an article on the theme, 'Should women practice dentistry? ${ }^{79}$ in the German dental journal, Korrespondenzblatt für Zahnärzte. From this article we learn that she had run her own practice successfully for seven years, that she practised oral surgery as well as operative dentistry, and emphasized the importance of restorative therapy. Like Henriette Hirschfeld, she treated only women and children at first but later men also. Kowarski-Blanc disputed the arguments against the so-called Frauenstudium. ${ }^{80}$ She sharply criticized the withholding of proper schooling from women, which restricted their abilities while, nevertheless, they were judged by men's standards on their eligibility to enter universities. She considered possible gender differences irrelevant to the question of equal opportunities in education. However, she described a special competence of women in the treatment of children. To Kowarski-Blanc, there was no doubt that women had the ability to practise dentistry and she explicitly made this claim for the entire professional field. She opposed the common thesis of her time that women are not suitable for surgery by giving an example of her own practice. She maintained that it is not physical strength but skill and an unfaltering mind that are needed in surgery, "and women could possess both just as men could lack both" ${ }^{81}$

A further source of information is the essay 'Die Zahnärztin' written by Ida Freudenheim in 1904; it was also reviewed in the dental press. Freudenheim pushed hard for the right of women to study dentistry and to work in this field, and she placed these demands within the framework of the struggle for women's liberation and equal rights. It was not women's special characteristics and abilities, nor their poor economic situation, that she wanted to draw attention to, but the "right of free self-determination" ${ }^{82}$ She explicitly demanded this right for married women, too. Freudenheim stated that female dental surgeons had the advantage of easily combining work and family life because their home was their workplace, and they could therefore organize their time effectively. She seemed to be right, because the evidence of later years showed that, compared with other academic fields, the number of married women and mothers working as dental surgeons was above average. ${ }^{83}$

Freudenheim listed employment by schools, the health insurance agencies and hospitals (especially paediatric hospitals) as well as self-employment, as possible vocational fields for women. Notably, Freudenheim made her position on the disputed school dentistry issue clear. She deplored the fact that so little was

\footnotetext{
${ }^{79}$ R Kowarski-Blanc, 'Noch einmal: Sollen Frauen als Zahnärzte prakticiren?', Korrespondenzblatt für Zahnärzte, 1896, 25: $302-6$.

${ }^{80}$ At the end of the nineteenth century, Frauenstudium was a common term which described the struggle of women for higher education, access to universities and professions. When women's demands for equal rights were no longer a matter of public debate this term was not used any more.
}

\footnotetext{
${ }^{81}$ Kowarski-Blanc, op. cit., note 79 above, p. 305 (translation by the author).

${ }^{82}$ Freudenheim, op. cit., note 43 above, p. 4 (translation by the author).

${ }^{83}$ See Christoph, op. cit., note 11 above, p. 25; C Grätz-Menzel, 'Über die rassenbiologische Wirkung der akademischen Frauenberufe mit besonderer Berücksichtigung der Ärztinnen und Zahnärztinnen', Archiv für Rassen- und Gesellschaftsbiologie, 1933, 27: 129-50, p. 141.
} 


\section{The Rise of German Dental Professionalism as a Gendered Project}

known of the severe health consequences for children of bad teeth, and that many parents did not even consider obtaining dental care for their children. However, she expected changes in the future. Her views were unquestionably ahead of her time, since school dentistry and prevention were by no means commonly recognized fields of work. She participated in the debate on the scientific and practical direction of dentistry and developed her own ideas for it. She demanded, for example, that dental surgeons should acquire a knowledge of nutrition and hygiene. "They should work on a social level by providing information to the community, thus improving public health" ${ }^{84}$

The writings of these female dental surgeons show that, even in the early years of their professional engagement, it was possible for women to become successful dental surgeons because there was a clear demand for their services. The treatment of women and children, in particular, opened up a new market for female dental surgeons and enabled them not only to equal the achievements of their male colleagues but also to surpass them. Further, school dentistry developed as a new speciality area which offered occupational chances for women.

The only argument articulated in favour of women's suitability for a specific professional field was their ability to care for children. It was this belief that made school dentistry seem a suitable vocational field for women. The apparent aptitude of women for treating children needed no defence since it was based on the cultural pattern that child care was a woman's responsibility. So convincingly "natural" did this argument appear that it needed no more elaboration. Further, women dental surgeons were supported by the strategy of their female medical colleagues, who were also trying to legitimize their claim to the profession by their treatment of women and children.

The gendered focus of their work did not influence female dental surgeons in the same way as female physicians. It was quite obvious from patients they treated that they had gendered assignments, but the female dental surgeons mentioned here did not accept any other type of restrictions; they extended their work to the whole therapeutic field of dentistry. ${ }^{85}$ The debate about oral surgery was forced on them, but it was the women themselves who introduced the debate on their suitability to treat children. This was a demand for appreciation of their specific abilities and by no means an acceptance of restrictions on their professional practice.

The fact that women had entered the profession at all created a situation that even opponents of an academic training for women were forced to accept. James Truman wrote: "The pioneer women have set a standard that can not, and should not, be overthrown". ${ }^{86}$ The initially male dominated profession was confronted by the need to re-define its gender relations.

\footnotetext{
${ }^{84}$ Freudenheim, op. cit., note 43 above, p. 24 (translation by the author).

${ }^{85}$ The arguments of women were similar in medicine and dentistry, yet the opportunities for women were different in the two professions. Professionalization in dentistry lagged far behind that in medicine; and the differentiation of the
} 


\section{Ellen Kuhlmann}

\section{Concessions and Defence Strategies: "The Women Question" within the Profession}

Dental surgeons were late in their response to the issue of the Frauenstudium. ${ }^{87}$ Amongst the earliest contributors to the debate in the 1880 s and 1890 s were two who advocated, without reservation, that women should practise dentistry and pointed explicitly to the success of women who had graduated in the United States. One also connected women's ability as dental surgeons, especially in surgery, with the particular manual skills which women develop in their early years. ${ }^{88}$ In 1892, however, the Zahnärztliches Wochenblatt published an article which represented a more negative view of female dental surgeons and their abilities. It pointed out that there was nothing new about women working in dentistry because of freedom of enterprise and the opportunities for training abroad. The author contended that women in the workforce were only a bad temporary solution; and that it was more appropriate for females to get married and care for children. His generally moderate disapproval for women dental surgeons increased when it came to surgery, which he claimed women would never be capable of performing. ${ }^{89}$ The same journal published two anonymous articles in its "notifications" column which also opposed the Frauenstudium. The first author disapproved of any kind of work for women, arguing that this would not only damage women's and children's health but would have a negative effect on family life. And, although it was articulated somewhat more moderately, the second letter was also a moral argument against the Frauenstudium, claiming negative effects on the shared reality of both men and women. ${ }^{90}$

Another dentist expressed a positive view of the Frauenstudium, and rejected the medical profession's intention to allow women entrance to dentistry but to exclude them from medicine. He saw no danger that the profession would be overrun by women. He admitted the ability of some women to "perform adeptly" in many fields, including medicine and dentistry. He also mentioned the treatment of children as a special area of work for women because the "soft hand of a female" was "more relieving and appeasing" to children."

A year later, the Korrespondenzblatt für Zahnärzte published an article entitled 'Should women practice dentistry?' It had a very contemptuous approach. Women's skill in surgery was vigorously denied, although the author admitted that children preferred to be treated by a female rather than a male dental surgeon. ${ }^{92}$ In the following year, the debate was re-opened by the dentist Blahy who developed further arguments against female dental surgeons. Blahy acknowledged that

\footnotetext{
${ }^{87}$ One early item was the anonymous, 'Kann ein Frauenzimmer Zahnarzt werden?', Der Zahnarzt, 1847, 1: 352.

${ }^{88}$ Journal für Zahnheilkunde, 1892, p. 353; 1888 , p. 53, quoted from Balschbach, op. cit., note 11 above, pp. $90-1$.

${ }^{89}$ Anon., 'Zur Frauenfrage', Zahnärztliches Wochenblatt, 1892, 6: 73-4.

${ }^{90}$ Quoted from Monse-Schneider, op. cit., note 11 above, pp. 36-7.
} 


\section{The Rise of German Dental Professionalism as a Gendered Project}

women were both mentally and physically capable of dentistry. But he was quite open in his belief that the issue was not one of skill but of competition. He predicted an increase in unmarried people and a decrease in status for the medical profession (Proletarisierung) as a result of female practice. In short: "Women will accelerate the catastrophe". ${ }^{93}$ However, at the Wiesbaden Physicians' Conference in 1898 the dentists expressed a somewhat less fatalistic view of the negative effects of women on professionalization. The conference discussed women's enrolment in medical schools, and it was concluded that dentistry would be suitable for women but medicine would not. On the other side, the Vereinsbund Deutscher Zahnärzte responded by stating that the reform process in the dental profession would be impeded by women. ${ }^{94}$

The dental press reacted to the medical devaluation of their profession not by statements opposing the Frauenstudium, but rather by demanding the equality of all medical departments. By contrast to the Vereinsbund, three articles published in the Zahnärztliches Wochenblatt following the Wiesbaden declaration reveal a positive approach to women's struggle for education. ${ }^{95}$ Only one of these three articles contained reservations, and, here again, it was oral surgery that was not conceded to women. ${ }^{96}$

The statements following the Wiesbaden conference seemed to mark the end of the debate in the dental press at the fin-de-siècle. ${ }^{97}$ It was not until 1914 that another dental surgeon, the executive director of the Wirtschaftlicher Verband der Zahnärzte, presented his view on women in dentistry. Compared to earlier articles, this was neither for nor against women enrolling or practising dentistry but about women's special skills, a theme which had merely been touched upon in earlier articles. For the first time, the focus of earlier debates on women dental surgeons, the special ability of women to treat children, was extended to the speciality of "orthodontics", which was almost exclusively practised on children anyway. School dental clinics were also seen as suitable places of work for women. "A softer use of instruments and maybe a more candid compassion and a milder comfort for the young patient" was, in the author's view, a skill that was specific to women. ${ }^{98}$ This article showed that approaches to the issue had changed: the general debate on the admission of women to the profession had been replaced by discussion of separation in the occupational field. But it is worth noting that the article was written at the outbreak of the First World War, when men were being drafted into military service and often replaced by women. ${ }^{99}$

\footnotetext{
${ }^{93}$ Blahy, 'Noch einmal: Sollten Frauen als Zahnärzte praktiziren?', Korrespondenzblatt für Zahnärzte, 1897, 26: $37-40$, on p. 39 (translation by the author).

${ }_{94}$ Groß, op. cit., note 9 above, p. 340.

${ }^{95}$ Anon., 'Ärztetag', Zahnärztliches Wochenblatt, 1898/99, 12: 73-4; Anon., 'Das Medizinstudium der Frauen', Zahnärztliches Wochenblatt, 1898/99, 12: 437-40; Anon., 'Zum Medizinstudium der Frauen', Zahnärztliches Wochenblatt, 1898/99, 12: 445-6.
}

\footnotetext{
${ }^{96}$ Ibid, p. 168.

${ }^{97}$ Balschbach, op. cit., note 11 above, and Monse-Schneider, op. cit., note 11 above, too, reported that discussion had come to an end.

${ }^{98} \mathrm{~K}$ Kaldewey, 'Soll die Frau Zahnärztin werden?', Zahnärztliche Mitteilungen, 1914, 42: 464 (translation by the author).

${ }_{99}^{9}$ For a summary, see L Lenemann, 'Medical women at war, 1914-1918', Med. Hist., 1994, 38: $160-77$, which analyses this process in the medical profession.
} 


\section{Ellen Kuhlmann}

In 1918, after the war, a last article on the subject was published: on the basis of Julius Schwalbe's paper on the advantages and disadvantages of women in medicine, the dental surgeon Hartkopf developed his own ideas. He granted that, although it had been in doubt, women had proved their skill in practice but he denied that they had any ability to achieve scientific status in medicine. ${ }^{100}$ Thus, even before the dental profession's long struggle for acknowledgement in the community of scientists had come to an end, men had already claimed exclusive rights in the field of science. In view of the sixteen articles published in the dental press between 1888 and 1918 on women's ability to study and to practise dentistry, one must conclude that there was no unanimous opinion on the subject within the dental profession. The spectrum of approach went from ubiquitous opposition to unconditional support of women's struggle for education. In six of these articles, the authors viewed female dental surgeons positively while ten were wholly or partly against them.

Dental surgeons tried to control developments by making the best of a bad situation: when it became obvious that they could not successfully bar women in the long run, they moved to secure male dominance in important areas. In the dental press, oral surgery was claimed by men from the very beginning. Not only was it a major field in dentistry but it was the only one completely accepted by the health insurance agencies. As a concession, they left women and child patients to their female colleagues. The strategy was not as generous as it may seem: because the feminist movement's demands for female physicians also influenced dental care, male dental surgeons faced the risk of losing this field anyway, at least in part, to female non-academic dentists. ${ }^{101}$ And successful woman like Henriette Hirschfeld proved that women actually had the ability to meet such demands.

This early gendering of the professional field was developed even further when school dentistry seemed to be suitable for women. At a later date, when orthodontic specialization developed, links were forged to school dentistry. ${ }^{102}$ Therefore it seemed "natural" that women should move into this high-prestige speciality area. ${ }^{103}$ It was this distinction-surgery for men and child treatment for women-which led to further gendering of speciality areas; although some, for example, operative dentistry, remained generally unaffected by the process.

\section{The Double Edge of Professionalization and Gender in Dentistry}

Feminist research often focuses on the strategies of closure and exclusion as specific to professionalization. ${ }^{104}$ But, as I have shown here, there was no

${ }^{100}$ Hartkopf, 'Das medizinische

Frauenstudium in Deutschland', Zahnärztliche

Mitteilungen, 1918, No. 6, 53-4.

${ }^{101}$ See Groß, op. cit., note 9 above.

${ }^{102}$ See, for example, Alfred Korach,

'Organisation der Berliner kommunalen

Zahnpflege', Soziale Medizin, 1928, 1: 305-10;

Martin Schwarz, 'Die soziale Aufgabe der

Orthodontie', Soziale Medizin, 1928, 1: 85-8.

\footnotetext{
${ }^{103}$ Ibid., p. 86, Schwarz described orthodontic therapy as being available to only a very small minority of rich people in the population.

${ }^{104}$ For example, Anne Witz, op. cit., note 2 above, who discusses the thesis of exclusion in the professionalization of medicine in Great Britain.
} 


\section{The Rise of German Dental Professionalism as a Gendered Project}

systematic displacement of women at the beginning of this process in dentistry because women had been working in this field in small numbers only. Professionalization had been a male project, but it was through its upward social mobility, and focus on medicine and academic training that dentistry became an objective for women who wanted to obtain access to the universities and to qualified professional work.

The success in opening up dentistry to women was due to several factors. The introduction of the health insurance system at the end of the nineteenth century resulted in an enormous expansion of the medical market. ${ }^{105}$ Toothaches were seen increasingly as an illness and therefore eligible for medical therapy. This cultural change of attitude was closely linked to the contracts made with the health insurance agencies when they extended their cover to dental care. This had an immediate economic effect on dental surgeons. ${ }^{106}$ The dental profession could not control the expanding market because of competing non-academic dentists. These low status dentists were seen as obstructing professionalization much more than the competition of women. ${ }^{107}$ The number of women in German dentistry was very low compared to the many unlicensed dentists. There was, therefore, no need for the profession to concentrate on strategies of defence against women.

Essential steps in professionalization had not yet been undertaken in dentistry, so it was difficult to initiate exclusive action against women, such as restricting them to low status or related sectors of the profession. This limited the scope of the dental surgeons and forced them rather to develop integrating strategies for women. Thus men offered a gendered division of the vocational field. This gender-typing - the females for the treatment of children, and the males for oral surgery-was rooted not only in cultural assumptions but also in occupational patterns inherited from an earlier period when the surgical crafts from which dentistry developed were exclusively male. Notably, women shared this attitude towards the treatment of children but did not accept exclusion from oral surgery. ${ }^{108}$ The gendering of dental care originated in the hierarchy of speciality areas, since oral surgery was much more prestigious and more profitable than the treatment of children, even though the framework here had potential for extension and reinterpretation. The discursive construction of "specialist areas versus patient groups" was only of use as a tool for gender hierarchy as long as the dominating role of surgery could be maintained. The emergence of dentistry as a science, already evident at the end of the nineteenth century, the change of attitude towards dental problems, and the health insurance agencies' decision on liability, paved the way for an expansion of the spectrum of dental care. Apart from oral

\footnotetext{
${ }^{105}$ For a summary, see Claudia Huerkamp, 'Entstehung und Ausdehnung der Gesetzlichen Krankenversicherung bis zum Inkrafttreten der Reichsversicherungsordnung 1914', in FriedrichWilhelm Schwartz et al. (eds), Public Health, Berlin, Springer, pp. 215-20; for the dental profession, see Axmann, op. cit., note 10 above; Vogel, op. cit., note 10 above.
}

\footnotetext{
${ }^{106}$ See Cohn, op. cit., note 38 above; Ziegeler, op. cit., note 10 above.

${ }^{107}$ This was an important difference to the attitudes in the medical profession, where overcrowding and devaluation by women was judged the main problem.

${ }^{108}$ See Freudenheim, op. cit., note 43 above; Kowarski-Blank, op. cit., note 79 above.
} 


\section{Ellen Kuhlmann}

surgery, other forms of treatment became important, for example, the public health oriented services for school children. Female dentists themselves maintained that women were more suitable for the treatment of children. They thus secured their own successful vocational field, developing new areas of practice in school dentistry and orthodontics. The gendering of the profession developed in parallel with the changes in scientific focus, government health policy and health insurance policy-all of which followed different patterns than the gender order. The overlap and the accumulation of distinctive structuring modes in the profession opened up new space for women. The concept of the expert, developed in the professionalization process, did not therefore necessarily turn out to be an advantage for the male actors. Acknowledged female expertise in the care of children enhanced the access of women to the profession, and eventually also to the highly prestigious speciality of orthodontics. 